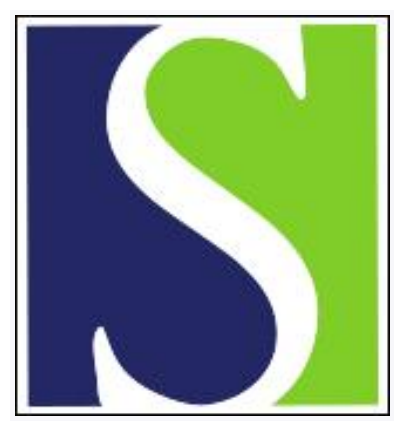

Scand J Work Environ Health 1994;20(4):235-242

https://doi.org/10.5271/sjweh.1402

Issue date: 01 Aug 1994

Mechanisms of the combined effect of asbestos and smoking in the etiology of lung cancer.

by Vainio $H$, Boffetta $P$

Affiliation: International Agency for Research on Cancer, Lyon, France.

The following article refers to this text: $2015 ; 41(4): 407-412$

This article in PubMed: www.ncbi.nlm.nih.gov/pubmed/7801068 


\title{
Mechanisms of the combined effect of asbestos and smoking in the etiology of lung cancer
}

\author{
by Harri Vainio, MD, Paolo Boffetta, MD'
}

\begin{abstract}
VAINIO H, BOFFETTA P. Mechanisms of the combined effect of asbestos and smoking in the etiology of lung cancer. Scand J Work Environ Health 1994;20:235-42. The joint effects of exposure to two known lung carcinogens, tobacco smoking and asbestos, are reviewed. The variable pattern of interaction - ranging from supramultiplicative to less than additive - may reflect the fact that both asbestos and smoking are complex carcinogens which can affect more than one stage of lung carcinogenesis. The joint effect of two such agents will depend on the relative magnitude of the effects at each stage. The epidemiologic evidence from studies of insulation workers with high exposures suggests an interaction that approximates the multiplicative model, indicating that each of the two factors has an independent action on the multistage process of carcinogenesis. Very limited information is available on the interaction between these two agents in causing specific histological types of lung cancer. Both tobacco smoke and asbestos fibers can be genotoxic and cytotoxic and cause proliferative lesions in the lungs. Tobacco smoke is known to contain carcinogens that bind to critical genes in DNA (deoxyribonucleic acid) and cause mutations. Asbestos fibers may cause chronic inflammation of the lungs, which releases various cytokines and growth factors, and therefore may provide a possible selective growth advantage for mutated cells.
\end{abstract}

KEY TERMS - adenocarcinoma, cancer, interaction, lung, review, tobacco smoking.

Lung cancer is the leading cause of death from cancer throughout the world (1). The major histological types of lung cancer are small-cell, squamouscell, and large-cell carcinomas and adenocarcinomas. Tobacco smoking causes all types of lung cancer, but the risk for squamous-cell and small-cell carcinomas of the lung is higher than that for adenocarcinoma (2). While tobacco smoking is the most important single cause of lung cancer, it is not a condition sine qua non. Increased risks for lung cancer have been demonstrated in nonsmoking populations with various occupational exposures, and increases in risk occur for both smokers and nonsmokers exposed occupationally to asbestos fibers (3). The risk for lung cancer associated with tobacco smoking is substantially increased in conjunction with exposure to asbestos, however, and therefore smoking and asbestos seem to have a more than additive action in causing lung cancer.

Lung cancer is not a single disease, and the various histological types have unique characteristics and may have specific etiologies. In this review, we examine the evidence for interaction between tobacco smoking and exposure to asbestos in causing lung cancer in general and various histopathological types

I International Agency for Research on Cancer, Lyon, France.

Reprint requests to: Dr H Vainio, International Agency for Research on Cancer, 150 cours Albert Thomas, F-69372 Lyon Cedex 08, France. of lung cancer in particular and discuss the possible underlying mechanisms of that interaction.

\section{Tobacco smoke as a lung carcinogen}

Carcinogenesis is conventionally regarded as a series of events that begins with the initiation of genetic alterations by an agent or agents that interact with deoxyribonucleic acid (DNA) and lead to heritable alterations. These "initiated" cells require further stimuli to divide during an extended period of tumor "promotion" and "progression." The long latency period between the initiation and diagnosis of cancer may reflect the latter stages.

The epidemiologic data on tobacco smoking and lung cancer are more extensive than those for any other cause of neoplasms in humans. Smoking can affect both early and late stages of carcinogenesis. Smoking in early life has a substantial effect on the risk for cancer in old age and therefore evidently affects at least one early stage. Giving up smoking in later life has a substantial effect on the risk five or ten years later, and therefore it also seems to affect at least one late stage (4).

Tobacco smoke contains more than 3500 chemicals (2). Smoking thus entails exposure to a variety of carcinogens, which include polycyclic aromatic hydrocarbons, such as benzo[a]pyrene, nitrosamines, and aromatic amines. Tobacco smoke is carcinogenic in animals. It induces micronuclei, sister chromatid exchanges, and cell transformation in vitro and has tumor-promoting activity in various test systems (2). 
Many of the carcinogens in tobacco smoke are activated metabolically into DNA-binding intermediates, mainly by reactions mediated by cytochrome P450. DNA adducts derived from tobacco smoke have now been detected in lung and other tissues of cigarette smokers (5-9).

In particular, adducts of benzo[a]pyrene diol epoxide to DNA have recently been detected in the lungs of smokers (10). This binding reaction is apparently activated via cytochrome P4501A1, the inducibility of which has been associated with a higher risk for lung cancer among smokers. (For a review, see reference 11.)

There is some evidence that macrophages can replace the $\mathrm{P} 450$ system in activating benzo[a]pyrene (12). Benzo[a)pyrene-7,8-dihydrodiol can be oxidized by activated macrophages to derivatives that are mutagenic, bind covalently to DNA, and induce sister chromatid exchange. (For a review, see reference 13.) Benzo[a]pyrene has been reported to cause oxidative damage in DNA about 20 times more frequently than it forms adducts (14).

\section{Action of asbestos in multistage carcinogenesis}

Asbestos is not a single mineral. The term covers several fibrous inorganic minerals that share specific properties but differ in chemical composition, morphology, durability, and, therefore, biological effects. All of the main types of asbestos fibers have, however, been shown to be carcinogenic in humans (3).

Advances have been made recently towards understanding the molecular mechanisms of asbestos-induced carcinogenesis. The cytotoxic, genotoxic, and proliferative effects of asbestos seem to be mediated in part by active oxygen species - reactive metabolites of oxygen that are produced from phagocytic cells or catalyzed by iron on the fiber surface $(15,16)$. (For a review see references 17 and 18.) Asbestos fibers can induce neoplastic cell transformation (19) and chromosome changes in vitro (20); workers exposed occupationally to asbestos have an increased incidence of double-strand breaks in lymphocyte DNA (21).

Asbestos fibers can be phagocytized by macrophages, which then release a wide variety of cytokines and mediators of inflammation that modulate growth and differentiation of the target cells. Damage to DNA in the inflammatory milieu surrounding asbestos fibers may lead to genetic alterations, such as the activation of protooncogenes or the inactivation of tumor suppressor genes, and result in the initiation of carcinogenesis and enhanced growth. Interactions of asbestos fibers with the DNA of their target cells can occur through various mechanisms, including oxidant activity and direct interactions with chromosomes. As a result, chromosome alterations and point mutations may occur in cellular protoon- cogenes and the expression of genes such as those coding for growth factors may be altered and ultimately lead to the development of tumors. (For a review, see references 17 and 18.)

\section{Interaction between asbestos and tobacco smoking in causing lung cancer}

In 1968, Selikoff and his co-workers (22) showed that the exposure of cigarette smokers to asbestos during insulation work was associated with a lung cancer risk far higher than that associated with each agent separately, a finding indicating an interaction between the two agents. Since the time of that seminal study, the asbestos-tobacco smoking-lung cancer paradigm has often been used as an example in methodological discussions of interactions.

In an epidemiologic study, interaction can be classified according to the statistical model that most closely describes the relationship between the observed relative risks among subjects exposed only to tobacco smoke (Rs), only to asbestos (Ra), and to both agents (Rsa), all relative risks being calculated in relation to subjects exposed to neither agent (23).

For any Rs and $\mathrm{Ra} \leq 1$, the two simplest models or relationships of interaction are the additive model $(\mathrm{Rsa}=\mathrm{Rs}+\mathrm{Ra}-1)$ and the multiplicative model $(\mathrm{Rsa}=\mathrm{Rs} \mathrm{Ra})(24,25)$. In this review, the absolute interaction magnitude, reconstructed from the figures available in the published reports, is classified with reference to these two models as follows: less than additive $(<A)$ for Rsa $<-25 \%$ of $A$; near additive ( A) for Rsa within $\pm 25 \%$ of $A$; additive (A) for Rsa within $\pm 10 \%$ of $A$; intermediate (I) for Rsa $>25 \%$ of A but below $-25 \%$ of $\mathrm{M}$; near multiplicative $(\sim \mathrm{M})$ for Rsa within $\pm 25 \%$ of M; multiplicative (M) for Rsa within $\pm 10 \%$ of $M$; and more than multiplicative ( $>$ M) for Rsa $>25 \%$ of $M$.

The statistical variability of the measure of interaction was not taken into consideration, but the measures of interaction are very imprecise as the small numbers of lung cancers among nonsmokers exposed to the two risk factors strongly reduce the statistical power. Even though several studies show a similar pattern of interaction, the available data are not sufficient to reject alternative models formally.

The largest epidemiologic studies of the interaction between tobacco smoking and exposure to asbestos are summarized in table 1 , which also gives the absolute measure of interaction derived from the original reports. The overall evidence indicates an interaction in the multiplicative region, although the pattern across studies was not uniform. In particular, an additive interaction was observed for Canadian chrysotile miners and millers (26-28), while for Australian underground crocidolite miners a more than multiplicative interaction was seen (29). For workers exposed to amosite or a combination of 
Table 1. Studies on the interaction between tobacco smoking and asbestos in the causation of lung cancer. $(P=$ exposure information collected prospectively from study subjects, $R=$ exposure information collected retrospectively from study subjects, $\mathrm{O}=$ exposure information collected from informants other than study subjects, for example, relatives, $D=$ exposure information collected from documents, $\mathrm{A}=$ additive, $\mathrm{M}=$ multiplicative, $\mathrm{I}=$ intermediate)

\begin{tabular}{|c|c|c|c|c|c|}
\hline \multirow{2}{*}{$\begin{array}{l}\text { Reference, design, location, } \\
\text { years of observation, and exposure }\end{array}$} & \multicolumn{2}{|c|}{ Exposure assessment } & \multicolumn{2}{|c|}{ Relative risk ${ }^{a}$} & \multirow[b]{2}{*}{ Interaction } \\
\hline & Smoking & Asbestos & Smokers & $\begin{array}{l}\text { Non- } \\
\text { smokers }\end{array}$ & \\
\hline $\begin{array}{l}\text { Berry et al (30), cohort, United Kingdom, } \\
1960-1970 \text {, mixed asbestos factory }\end{array}$ & $\mathrm{D}, \mathrm{O}$ & $\mathrm{D}$ & $\begin{array}{l}2.3^{c} \\
7.4^{\text {d }}\end{array}$ & 5.0 & $\begin{array}{l}{[>\mathrm{M}]} \\
{[>\mathrm{M}]}\end{array}$ \\
\hline $\begin{array}{l}\text { Selikoff \& Hammond (35), cohort, United States, } \\
1963-1974 \text {, chrysotile and amosite } \\
\text { in insulation work }\end{array}$ & $\mathbf{P}$ & $D$ & {$[6.0]$} & {$[0]$} & {$[>M]$} \\
\hline $\begin{array}{l}\text { Martischnig et al (39), case-referent, United } \\
\text { Kingdom, 1973-1974, any asbestos exposure }\end{array}$ & $\mathrm{R}$ & $\mathrm{R}$ & {$[3.2]$} & 1.1 & $>M$ \\
\hline $\begin{array}{l}\text { Blot et al (36), case-referent, United States, } \\
1970-1976, \text { shipyards }\end{array}$ & $\mathrm{R}, \mathrm{O}$ & $\mathrm{R}, \mathrm{O}$ & {$[1.6]$} & {$[1.3]$} & $\sim M$ \\
\hline $\begin{array}{l}\text { Hammond et al (37), cohort, United States and } \\
\text { Canada, 1967-1976, chrysotile and amosite } \\
\text { in insulation work }\end{array}$ & $P$ & $\mathrm{D}$ & {$[5.3]$} & {$[5.7]$} & $M$ \\
\hline $\begin{array}{l}\text { Selikoff et al (31), cohort, United States, } \\
1961-1977 \text {, amosite factory }\end{array}$ & $\mathbf{P}$ & $\mathrm{D}$ & 4.7 & 25 & 1 \\
\hline $\begin{array}{l}\text { Blot et al (38), case-referent, United States, } \\
1972-1976, \text { shipyards }\end{array}$ & 0 & 0 & {$[1.6]$} & [1.9] & $\sim M$ \\
\hline $\begin{array}{l}\text { Pastorino et al (40), case-referent, Italy, } \\
1976-1979 \text {, any asbestos exposure }\end{array}$ & $\mathrm{R}$ & $\mathrm{R}$ & {$[1.8]$} & {$[2.8]$} & 1 \\
\hline $\begin{array}{l}\text { Acheson et al (32), cohort, United Kingdom, } \\
1947-1980 \text {, amosite factory }\end{array}$ & D & $\mathrm{D}$ & [1.6] & {$[2.0]$} & {$[\sim M]$} \\
\hline $\begin{array}{l}\text { Liddell et al (28), case-referent in cohort, Canada, } \\
1950-1975 \text {, chrysotile mining and milling }\end{array}$ & $O, P$ & $\mathrm{D}$ & {$[1.7]$} & {$[3.0]$} & $\sim \mathrm{A}$ \\
\hline $\begin{array}{l}\text { Baker ( } 29) \text {, cohort, Australia, 1944-1981, } \\
\text { crocidilite mining and milling }\end{array}$ & $P$ & $\mathrm{D}$ & {$[5.0]$} & 0.7 & $>\mathrm{M}$ \\
\hline $\begin{array}{l}\text { Hilt et al (34), cohort, Norway, } 1966-1973 \text {, } \\
\text { maintenance workers exposed to asbestos }\end{array}$ & $P$ & $\mathrm{D}$ & {$[4.3]$} & 0 & $>\mathrm{M}$ \\
\hline $\begin{array}{l}\text { Berry et al (33), cohort, United Kingdom, } \\
1971-1980 \text {, mixed asbestos factory }\end{array}$ & $\mathrm{P}$ & $\mathrm{D}$ & $\begin{array}{l}2.0^{c} \\
4.3^{\mathrm{d}}\end{array}$ & $\begin{array}{r}6.3 \\
12.5\end{array}$ & $\begin{array}{l}{[\mathrm{A}]} \\
{[\mathrm{I}]}\end{array}$ \\
\hline $\begin{array}{l}\text { Kjuus et al (41), case-referent, } \\
\text { Norway, 1979-1983, any asbestos exposure }\end{array}$ & $R$ & $\mathrm{R}$ & [2.1] & {$[2.4]$} & $\sim \mathrm{M}$ \\
\hline $\begin{array}{l}\text { De Klerk et al (42), case-referent in cohort, } \\
\text { Australia, 1979-1986, crocidolite miners }\end{array}$ & $P$ & $\mathrm{D}$ & 2.6 & 1.9 & $>M$ \\
\hline $\begin{array}{l}\text { Cheng \& Kong (43), cohort, China, } \\
1972-1987 \text {, mixed asbestos factories }\end{array}$ & $D$ & D & 1.6 & 1.6 & $M$ \\
\hline
\end{tabular}

a Relative risk due to asbestos exposure; numbers in square brackets have been reconstructed from published data.

b For definitions of the categories of interaction, see the text. The categories in square brackets have been based on the as. sumption of a relative risk due to smoking $=10$.

c Men.

d Women.

amosite, chrysotile, and crocidolite in manufacturing, variations were seen in the size of the observed interaction $(30-34)$. However, studies of highly exposed insulators (35-38) and case-referent studies of any type of asbestos exposure (39-41) showed a more uniformly multiplicative pattern.

A case-referent analysis nested in the cohort of Australian crocidolite miners (42) confirmed the pattern of a more than multiplicative interaction, while in a recently published study from China on workers exposed to chrysotile asbestos in various manufacturing industries, a multiplicative interaction was seen (43).

In conclusion, a variable pattern of interaction has been observed which may reflect both the fact that asbestos and smoking act at different stages of the carcinogenic process and the fact that there are differences in the biological effects of different types of asbestos fibers (23). Overall, however, studies of workers exposed to high levels of asbestos, such as insulator workers, point to an interaction that approximates the multiplicative model.

\section{Interaction between asbestos and tobacco smoking in causing different histological types of lung cancer}

It is often claimed that adenocarcinoma is the histological type of lung cancer most frequently associated with exposure to asbestos. However, Churg (44) provided evidence that this claim may not be true. 
He examined the studies in which the distribution of cases of lung cancer with an association to asbestos exposure and those without such an association was reported by cell type. Table 2 adds a few recent studies to the data reported by Churg and gives more details on the exposed and reference populations used in each study. When cases of squamous-cell carcinoma are taken as the reference group, a significant, positive association is seen between exposure to asbestos and small-cell carcinoma, but no association is seen with either adenocarcinoma or large-cell carcinoma. The data reported in table 2 do not allow any conclusion to be drawn with respect to specific types of asbestos fiber.

A few recent studies also provide results on the risks for specific cell types of lung cancer associated with asbestos exposure. In a case-referent study in Japan, Minowa and his co-workers (50) found a significantly increased risk for Kreyberg I lung cancer (small-cell and squamous-cell carcinoma) after exposure to asbestos, as estimated from job titles [odds ratio (OR) 3.40], and a lower, nonsignificant risk (OR 1.72 total number of exposed cases 38) for Kreyberg II lung cancer (adenocarcinoma). In a cohort study of Danish asbestos-cement workers, who were mainly exposed to chrysotile, the standardized incidence ratio (SIR) was higher for adenocarcinoma [SIR 3.31, 95\% confidence interval $(95 \% \mathrm{CI})$ $2.12-4.92$, cases 24$]$ than for squamous-cell carcinoma (SIR 1.67, 95\% CI 1.18-2.31, cases 37); a trend was seen for adenocarcinoma, but not for squamous-cell carcinoma, according to the duration of exposure and latency (51). Finally, in a study on lung cancer cases in Finland, in which smoking was adjusted for, the odds ratio for adenocarcinoma associated with exposure to asbestos (measured as $\geq 3 \cdot 10^{6}$ fibers $\cdot g$ lung tissue $\left.{ }^{-1}\right)$ was $3.4(90 \%$ CI $0.7-15)$ when compared with squamous-cell carci-

Table 2. Number of cases of lung cancer by exposure to asbestos and cell type in selected studies.

\begin{tabular}{|c|c|c|c|c|c|c|c|c|c|}
\hline \multirow{2}{*}{$\begin{array}{l}\text { Reference, location, } \\
\text { time, exposed } \\
\text { population }\end{array}$} & \multirow{2}{*}{$\begin{array}{l}\text { Unexposed } \\
\text { population }\end{array}$} & \multicolumn{2}{|c|}{$\begin{array}{l}\text { Squamous-cell } \\
\text { carcinoma }\end{array}$} & \multicolumn{2}{|c|}{$\begin{array}{l}\text { Small-cell } \\
\text { carcinoma }\end{array}$} & \multicolumn{2}{|c|}{$\begin{array}{c}\text { Adeno- } \\
\text { carcinoma }\end{array}$} & \multicolumn{2}{|c|}{$\begin{array}{l}\text { Large-cell } \\
\text { carcinoma }\end{array}$} \\
\hline & & $\begin{array}{l}\text { Exposed } \\
\text { cases }\end{array}$ & $\begin{array}{l}\text { Un- } \\
\text { exposed } \\
\text { cases }\end{array}$ & $\begin{array}{l}\text { Exposed } \\
\text { cases }\end{array}$ & $\begin{array}{l}\text { Un- } \\
\text { exposed } \\
\text { cases }\end{array}$ & $\begin{array}{l}\text { Exposed } \\
\text { cases }\end{array}$ & $\begin{array}{l}\text { Un- } \\
\text { exposed } \\
\text { cases }\end{array}$ & $\begin{array}{c}\text { Exposed } \\
\text { cases }\end{array}$ & $\begin{array}{l}\text { Un. } \\
\text { exposed } \\
\text { cases }\end{array}$ \\
\hline $\begin{array}{l}\text { Kannerstein \& Churg (45), } \\
\text { United States (period and } \\
\text { source of cases not } \\
\text { specified), any type of } \\
\text { asbestos }\end{array}$ & $\begin{array}{l}\text { Cases without } \\
\text { history of asbestos } \\
\text { exposure, matched } \\
\text { by diagnostic } \\
\text { procedure }\end{array}$ & 11 & 12 & 11 & 14 & 11 & 9 & 6 & 8 \\
\hline $\begin{array}{l}\text { Martschnig et al (39), } \\
\text { United Kingdom, 1972- } \\
1973 \text {, cases from one } \\
\text { hospital, self-reported } \\
\text { exposure to any type } \\
\text { of asbestos }\end{array}$ & $\begin{array}{l}\text { Cases without } \\
\text { self-reported } \\
\text { exposure }\end{array}$ & 26 & 77 & 22 & 27 & 1 & 8 & - & - \\
\hline $\begin{array}{l}\text { Auerbach et al (46), } \\
\text { United States, 1966-1979, } \\
\text { three hospitals and } \\
\text { a cohort of insulation } \\
\text { workers, exposure to any } \\
\text { type of asbestos derived } \\
\text { from occupational history }\end{array}$ & $\begin{array}{l}\text { Cases from } \\
\text { same hospitals }\end{array}$ & 96 & 335 & 48 & 102 & 29 & 122 & 20 & 89 \\
\hline $\begin{array}{l}\text { Ives et al (47), } \\
\text { United States, } \\
\text { World War II, } \\
\text { shipbuilding workersa }\end{array}$ & $\begin{array}{l}\text { Cases from same } \\
\text { hospitals }\end{array}$ & 24 & 103 & 7 & 27 & 5 & 31 & - & - \\
\hline $\begin{array}{l}\text { Baker et al (48), } \\
\text { Australia, 1958-1978, } \\
\text { crocidolite miners }\end{array}$ & $\begin{array}{l}\text { Cases from same } \\
\text { province, matched } \\
\text { by age and year } \\
\text { of diagnosis }\end{array}$ & 21 & 76 & 9 & 46 & 9 & 64 & 6 & 32 \\
\hline $\begin{array}{l}\text { Mollo et al }(55) \\
\text { Italy, } 1982-1986, \\
\text { exposure to any type } \\
\text { of asbestos derived from } \\
\text { occupational history }\end{array}$ & $\begin{array}{l}\text { Definite or } \\
\text { probable exposure } \\
\text { versus possible } \\
\text { or no exposure }\end{array}$ & 22 & 205 & 1 & 21 & 15 & 97 & 4 & 33 \\
\hline $\begin{array}{l}\text { Johansson et al (49), } \\
\text { Sweden, } 1953-1986, \\
\text { asbestos cement works } \\
\text { (>95\% chrysotile) }\end{array}$ & $\begin{array}{l}\text { Cases from same } \\
\text { hospital, matched } \\
\text { by diagnostic } \\
\text { procedure, age, } \\
\text { year of duration } \\
\text { and gender }\end{array}$ & 11 & 42 & 5 & 28 & 9 & 13 & 4 & 13 \\
\hline $\begin{array}{l}\text { Odds ratio for asbestos } \\
\text { exposureb } \\
95 \% \text { confidence interval }\end{array}$ & & 1 (refe & erence) & 1.33 & -1.76 & 0.93 & -1.25 & $0.56-$ & -1.23 \\
\hline
\end{tabular}

a Data provided by W Blot (personal communication).

b Mantel-Haenszel odds ratio. 
noma, on the basis of nine and four exposed cases, respectively (52).

The differences in the results on the association between asbestos exposure and specific cell types of lung cancer may be due to inadequate control for confounding factors. The source of cases may be an important variable, as shown by Whitwell and his coworkers (53), who compared the proportions of different cell types in series of biopsy samples, surgical specimens, and necropsy samples. They found a lower proportion of adenocarcinomas in the biopsy series than in the necropsy series, and an opposite pattern for squamous-cell carcinoma. Other aspects that may play a role are the type of asbestos fiber and characteristics of the exposure pattern, such as duration and intensity.

Tobacco smoking increases the risk of all main types of lung cancer. However, the risks of squamous-cell and small-cell carcinomas of the lung are increased to a greater extent than that of adenocarcinomas (2).

Very little information is available on the interaction between tobacco smoking and exposure to asbestos in causing different histological types of lung cancer. In a case-referent study of white male patients admitted to a large hospital in New York State in the United States, occupational exposure to asbestos was assessed from the job titles reported by the patients (54). Figure 1 shows the number of cases and the relative risks according to cell type and exposure to smoking and asbestos. On the basis of the categories used in table 1 , the interaction is $\sim \mathrm{M}$ for squamous-cell carcinoma, $\sim \mathrm{A}$ for small-cell carcinoma, and $\mathrm{A}$ for adenocarcinoma. A series of lung cancer patients seen at a hospital in Turin, Italy, was interviewed with respect to asbestos exposure and smoking habits (55), and asbestos bodies were counted in samples of normal lung tissue. A case-case analysis was then carried out in which cases of adenocarcinoma were compared with cases of squamous-cell carcinoma. The term for interaction between tobacco smoking (more than 20 cigarettes per day versus $0-20$ cigarettes per day) and exposure to asbestos (definite or probable exposure versus possible or no exposure) was negative (OR $0.94,95 \%$ CI $0.23-$ 3.86 ), while that between smoking and asbestos body count (more than 10000 bodies $\cdot \mathrm{g}^{-1}$ versus up to 10000 bodies $\cdot \mathrm{g}^{-1}$ ) was positive (OR $1.82,95 \%$ CI 0.08 - 41.7). Neither interaction term was statistically significant and therefore suggested that there was no difference according to histological type in the interaction between exposure to asbestos and tobacco smoking. Both terms were, however, highly imprecise.

The report of the study (52) on lung cancer cases from Helsinki, Finland, provided enough detail to allow an ad hoc analysis of the interaction between smoking (categorized as $<50$ pack-years versus more) and asbestos exposure (up to $3 \cdot 10^{6}$ fibers $\cdot g$ lung tissue ${ }^{-1}$ versus more) by cell type. The age-ad-

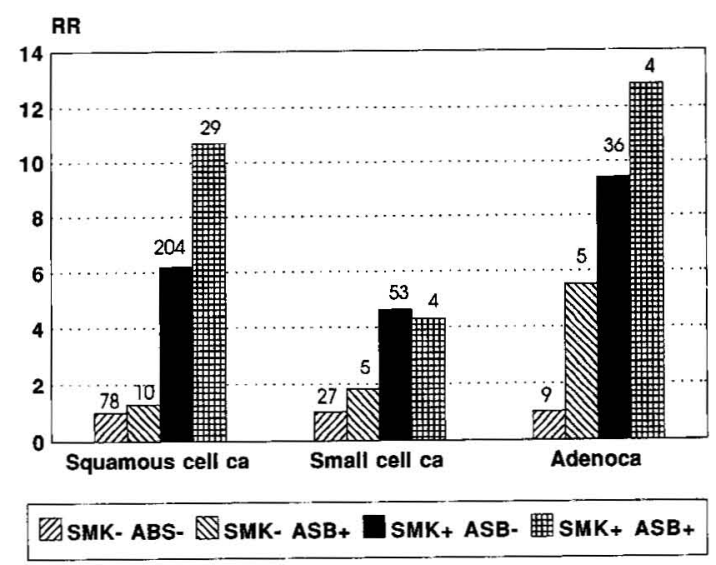

Figure 1. Numbers of cases and the relative risks according to lung cancer cell type and exposure to smoking and asbestos. The results derive from the case-referent study of Vena et al (49). The analysis was based on crude data. Smoking (SMK) exposure is categorized as 0-39 pack-years (SMK-) versus $\geq 40$ pack-years (SMK + ). Asbestos (ASB) exposure is categorized as never (ASB-) versus ever (ASB+) exposed. The reference category is SMK-ASB-. The numbers of referents were as follows: SMK- ASB- 718, SMK$\mathrm{ASB}+72, \mathrm{SMK}+\mathrm{ASB}-304, \mathrm{SMK}+\mathrm{ASB}+25$. (ca = carcino$\mathrm{ma}$, Adenoca $=$ adenocarcinoma)

justed odds ratios for adenocarcinoma, using squamous-cell carcinoma as the reference, were 1.1 (95\% CI $0.1-9.3$ ) for the subjects exposed to asbestos but not to smoking, $0.4(95 \% \mathrm{CI} 0.1-2.8)$ for the subjects exposed to smoking but not to asbestos, and 3.2 (95\% CI 0.6-20) for the subjects exposed to both, as compared with subjects exposed to neither agent, a finding suggesting a stronger interaction (ie, closer to $>\mathrm{M}$ than $<\mathrm{A}$ ) between exposure to asbestos and smoking in the occurrence of adenocarcinoma than in the occurrence of squamous-cell carcinoma.

\section{Biological basis of the combined effect}

In an attempt to explain the multiplicative increase in the risk for lung cancer associated with combined exposure to asbestos and tobacco smoke, hamsters were given intratracheal instillations of asbestos fibers and benzo[a]pyrene. The substances induced tumors only when given in combination (56). The mechanisms of the joint effect are not known. It is possible that fibers enhance the penetration of tobacco smoke constituents (such as benzo[a]pyrene) into cells. Cigarette smoke condensate in combination with crocidolite asbestos induces the formation of hydroxyl radicals and DNA strand breaks in isolated DNA (57). Asbestos fibers can cause inflammatory reactions, oxygen radical bursts, and, after longterm exposure, fibrosis of the lungs. Tobacco smoke contains several carcinogenic chemicals that bind to DNA and activate protooncogenes and tumor suppressor genes. Activated oxygen species induce mu- 
tations in mammalian cells (58). Recently, there has been a surge of interest in the role of nitrogen oxide and its derivatives in the pathobiology of chronic infection and its relationship to the carcinogenic process (59). Macrophages produce inflammatory cytokines and oxygen radicals when exposed to asbestos fibers, and it was reported recently that macrophages also produce nitric oxide in response to asbestos (60). Tobacco smoke contains up to $600 \mu \mathrm{g}$ of nitric oxide and other nitrogen oxides per cigarette (2, p 95). Excess nitric oxide is mutagenic and induces DNA damage by deaminating nucleotide bases, such as 5-methylcytosine, and inducing strand breaks.

Damage to DNA is critical to the process of initiation in the multistage model of carcinogenesis, and the joint effect of exposure to tobacco smoke and asbestos depends on the relative magnitude of the effects on mutation rates and on the rate of clonal expansion of mutated cells (61). The DNA modification must be sufficiently tenacious to escape efficient repair processes but not so excessive that cell death results. Common sites for point mutations, in both the K-ras gene and the 553 suppressor gene, are guanine:cytosine base pairs in deoxycytidine-3', $5^{\prime}$ deoxyguanosine dinucleotide sequences $(62,63)$, so that guanine:cytosine base pairs in both tumor suppressor genes and protooncogenes may represent vulnerable targets for mutation. As has already been described, exposure to asbestos is associated with an excess occurrence of adenocarcinomas in some studies, and adenocarcinomas have a higher frequency of K-ras mutations than squamous-cell carcinomas do (52). In a Finnish study of lung adenocarcinoma patients, mutations in the K-ras gene were present in $46 \%$ (17 of 37), and guanine-to-thymine transversions were the predominant type of mutation $(41 \%$, 7 of 17) (Ridanpää et al, unpublished manuscript). Smoking is associated with guanine-to-thymine transversions in codon 12 of the $\mathrm{K}$-ras gene, which can be caused, for example, by benzo[a]pyrene. Asbestos fibers can, under suitable circumstances, hydroxylate 2-deoxyguanosine to 8-hydroxydeoxyguanosine, mediated by hydroxyl radicals (64); the presence of 8-hydroxyguanine in DNA would also lead to guanine-to-thymine transversions. Guanine-to-adenine and cytosine-to-thymine transitions are also fairly common in lung tumors, especially in the p53 gene (65). The deamination of 5-methylcytosine at cytosine-guanosine dinucleotides by nitric oxide has been suggested to cause cytosine-to-thymine transitions in vivo $(66,67)$. Exposure to asbestos may increase the frequency of transition and transversion mutations indirectly via oxygen radical or nitric oxide pathways (65) and therefore increase the likelihood of $\mathrm{K}$-ras mutations in adenocarcinomas (52, 68). Another mechanism could be enhancement of clonal expansion, improved recruitment of mutated cells, and a selective growth advantage to mutated cells.

\section{Concluding remarks}

The joint effect of two exposures, both of which affect more than one stage of carcinogenesis, depends on the relative magnitude of the effects on early and late stages. Tobacco smoke and asbestos fibers may have interdependent effects on the multistage process of lung carcinogenesis. Tobacco smoke can act at early stages, inducing genetic alterations, DNA adducts, and mutations in genes critical to oncogenesis, and the epidemiologic evidence suggests that tobacco smoke may also act at later stages of carcinogenesis. Asbestos fibers can be cytotoxic and genotoxic and cause proliferative lesions in the lungs, mediated in part by oxygen radicals and nitrogen oxides. Chronic inflammation of the lungs can release various cytokines and growth factors which may provide a selective growth advantage to mutated cells.

The epidemiologic evidence for the interaction between asbestos and tobacco smoking is clearest in studies of workers exposed to high levels of asbestos (ie, asbestos insulation workers), and that evidence points to an interaction that approximates the multiplicative model. In other situations, a variable pattern of interaction has been observed. Tobacco smoking increases the risk for adenocarcinoma of the lung to a less extent than other major histological types. Asbestos exposure is associated with an excess occurrence of adenocarcinomas in some, but not all, studies. Unfortunately, the existing data for assessing the interaction for a particle histological subtype of lung cancer are weak, and further epidemiologic studies are warranted.

\section{Acknowledgments}

We are grateful to $\mathrm{H}$ Oshima, $\mathrm{PhD}$, for making helpful comments on the text, to E Heseltine, MSc, for editing the text, and to Ms J Mitchell for typing the manuscript.

\section{References}

1. Pisani P, Parkin DM, Ferlay J. Estimates of the worldwide mortality from eighteen major cancers in 1985: implications for prevention and projections for future burden. Int J Cancer 1993;55:891-903.

2. International Agency for Research on Cancer (IARC). Tobacco smoking. Lyon: IARC, 1986. IARC monographs on the evaluation of the carcinogenic risk of chemicals to humans, vol 38 .

3. International Agency for Research on Cancer (IARC). Overall evaluations of carcinogenicity: an updating of IARC monographs volumes $1-42$. Lyon: IARC, 1987. IARC monographs on the evaluation of carcinogenic risks to humans, suppl 7.

4. Doll R, Peto R. Cigarette smoking and bronchial carcinoma: dose and time relationships among regular smokers and lifelong non-smokers. J Epidemiol Community Health 1978;32:303-13.

5. Everson RB, Randerath E, Santella RM, Cefalo RC, Avitts TA, Randerath K. Detection of smoking-relat- 
ed covalent DNA adducts in human placenta. Science 1986;231:54-7.

6. Everson RB, Randerath E, Santella RM, Avitts TA, Weinstein IB, Randerath K. Quantitative associations between DNA damage in human placenta and maternal smoking and birth weight. JNCI 1988;80:567-75.

7. Phillips DH, Hewer A, Martin CN, Garner RC, King MM. Correlation of DNA adduct levels in the human lung with cigarette smoking. Nature 1988;336:7902.

8. Cusick J, Routledge MN, Jenmkinc D, Courner RC. DNA adducts in different tissues of smokers and nonsmokers. Int J Cancer 1990;45:673-8.

9. Geneste O, Camus A-M, Castegnaro M, Petruzzelli S, Macchiarini P, Angeletti CA, et al. Comparison of pulmonary DNA adduct levels, measured by ${ }^{32} \mathrm{P}$-postlabelling and aryl hydrocarbon hydroxylase activity in lung parenchyma of smokers and ex-smokers. Carcinogenesis $1991 ; 12: 1301-5$.

10. Alexandrov K, Rojas M, Geneste O, Castegnaro M, Camus A-M, Petruzzelli S, et al. An improved fluorimetric assay for dosimetry of benzo(a)pyrene diolepoxide-DNA adducts in smokers' lung: comparisons with total bulky adducts and aryl hydrocarbon hydroxylase activity. Cancer Res 1992;52:6248-53.

11. Vähäkangas K, Pelkonen O. Host-variations in carcinogenic metabolism and repair. In: Lynch HT, Hirayama T, editors. Genetic epidemiology of cancer. Boca Raton, FL: CRC Press, 1989:35-54.

12. Trush MA, See JL, Kensler TW. Oxidant-dependent metabolic activation of polycyclic aromatic hydrocarbons by phorbol ester-stimulated human polymorphonuclear leukocytes: possible link between inflammation and cancer. Proc Natl Acad Sci USA 1985;82: 5194-8.

13. Weitzman SA, Gordon LI. Inflammation and cancer: role of phagocyte-generated oxidants in carcinogenesis. Blood 1990;76:655-63.

14. Ide ML, Kaneco M, Cerutti P. Benzo[a]pyrene and ascorbate- $\mathrm{CuSO}_{4}$ induce DNA damage in human cells by indirect action. In: McBrian DCH, Slater TF, editors. Protective agents in cancer. New York, NY: Academic Press, 1983;125-40.

15. Lund LG, Aust AE. Iron mobilization from crocidolite asbestos greatly enhances crocidolite-dependent formation of DNA single-straind breaks in $\phi X 174 \mathrm{RFI}$ DNA. Carcinogenesis 1992;13:637-42.

16. Korkina LG, Durnev AD, Suslova TB, Cheremisina ZP, Daugel-Dauge NO, Afanas'ev IB. Oxygen radical-mediated mutagenic effect of asbestos on human lymphocytes: suppression by oxygen radical scavengers. Mutat Res 1992;265:245-53.

17. Barrett JC. Mechanisms of action of known human carcinogens. In: Vainio H, Magee P, McGregor D, McMichael AJ, editors. Mechanisms of carcinogenesis in risk identification. Lyon: International Agency for Research on Cancer (IARC), 1992; 115-34. IARC scientific publications, no 116.

18. Mossman BT. Mechanisms of asbestos carcinogenesis and toxicity: the amphibole hypothesis revisited [editorial]. Br J Ind Med 1993;50:673 - 6.

19. Hesterberg TW, Barrett JC. Dependence of asbestosand mineral dust-induced transformation of mammalian cells in culture on fiber dimension. Cancer Res 1984;44:2170-80.

20. Oshimura M, Hesterberg TW, Tsutsui T, Barrett JC. Correlation of asbestos-induced cytogenetic effects with cell transformation of Syrian hamster embryo cells in culture. Cancer Res 1984;44:5017-22.

21. Marczynski B, Czuppon AB, Marek W, Reichel G, Baur, X. Increased incidence of DNA double-strand breaks and anti-ds DNA antibodies in blood of workers occupationally exposed to asbestos. Human Exp Toxicol 1994;13:3-9.
22. Selikoff IJ, Hammond EC, Churg J. Asbestos exposure, smoking, and neoplasia. JAMA 1968;204:10410.

23. Saracci R, Boffetta P. Interactions of tobacco smoking with other causes of lung cancer. In: Samet J, editor. Epidemiology of lung cancer. New York, NY: Marcel Dekker, 1994;471-99.

24. Rothman KJ. The estimation of synergy or antagonism. Am J Epidemiol 1976;103:506-11.

25. Saracci R. Interaction and synergism. Am J Epidemiol 1980;112:465-6.

26. McDonald JC, Liddell FDK, Gibbs GW, Eyssen GE, McDonald AJ. Dust exposure and mortality in chrysotile mining 1910 - 75. Br J Ind Med 1980;37:11-24.

27. Thomas DC. Statistical methods for analyzing effects of temporal patterns of exposure on cancer risks. Scand J Work Environ Health 1983;9:353-66.

28. Liddell FDK, Thomas DC, Gibbs JW, McDonald JC. Fibre exposure and mortality from pneumoconiosis, respiratory and abdominal malignancies in chrysotile production in Quebec, 1926-75. Ann Acad Med Singapore $1984 ; 13$ suppl 2:340-4.

29. Baker JE. Lung cancer incidence amongst previous employees of an asbestos mine in relationship to crocidolite exposure and tobacco smoking [thesis]. Perth: University of Western Australia, 1985.

30. Berry G, Newhouse ML, Turok M. Combined effect of asbestos exposure and smoking on mortality from lung cancer in factory workers. Lancet 1972;2:4769.

31. Selikoff IJ, Seidman H, Hammond EC. Mortality effects of cigarette smoking among amosite asbestos factory workers. JNCI 1980;65:507-13.

32. Acheson ED, Gardner JM, Winter PD, Bennett C. Cancer in a factory using amosite asbestos. Int J Epidemiol 1984;13:3-10.

33. Berry G, Newhouse ML, Antonis P. Combined effect of asbestos and smoking on mortality from lung cancer and mesothelioma in factory workers. Br J Ind Med 1985;42:12-8.

34. Hilt B, Langård S, Andersen A, Rosenberg J. Asbestos exposure, smoking habits, and cancer incidence among production and maintenance workers in an electrochemical plant. Am J Ind Med 1985;8:565-77.

35. Selikoff IJ, Hammond ED. Multiple risk factors in environmental cancer. In: Fraumeni J, editor. Persons at high risk of cancer. New York, NY: Academic Press, 1975:467-83.

36. Blot WJ, Harrington JM, Toledo A, Hoover R, Heath CW. Fraumeni JF Jr. Lung cancer after employment in shipyards during World War II. N Engl J Med 1978; 299:620-4.

37. Hammond EC, Selikoff IJ, Seidman H. Asbestos exposure, cigarette smoking and death rates. Ann NY Acad Sci 1979;330:473-90.

38. Blot WJ, Morris LE, Stroube R, Tagnon I, Fraumeni JF. Lung and laryngeal cancer in relation to shipyard employment in coastal Virginia. JNCI 1980;65:5715 .

39. Martischnig KM, Newell DJ, Barnsley WC, Cowan WK, Feinmann EL, Oliver E. Unsuspected exposure to asbestos and bronchogenic carcinoma. $\mathrm{Br}$ Med J $1977 ; 1: 746-9$

40. Pastorino U, Berrino F, Gervasio A, Pesenti V, Riboli E, Crosignani P. Proportion of lung cancers due to occupational exposure. Int J Cancer 1984;33:231-7.

41. Kjuus $H$, Skjærven $R$, Langård $S$, Lien JT, Aamodt $T$. A case-referent study of lung cancer, occupational exposures and smoking: II. role of asbestos exposure. Scand J Work Environ Health 1986;12:203-9.

42. De Klerk NH, Musk AW, Armstrong BK, Hobbs MST. Smoking, exposure to crocidolite, and the incidence of lung cancer and asbestosis. Br J Ind Med 1991;48: $412-7$. 
43. Cheng WN, Kong J. A retrospective mortality cohort study of chrysotile asbestos products workers in Tianjin 1972-1987. Environ Res 1992;59:271-8.

44. Churg, A. Lung cancer cell type and asbestos exposure. JAMA 1985;253:2984-5.

45. Kannerstein M, Churg J. Pathology of carcinoma of the lung associated with asbestos exposure. Cancer 1972;30:14-21.

46. Auerbach 0, Garfinkel L, Parks VR, Conston AS, Galdi VA, Joubert L. Histologic type of lung cancer and asbestos exposure. Cancer 1984;54:3017-21.

47. Ives JC, Buffler PA, Greenberg SD. Environmental association and histopathological patterns of carcinoma of the lung: the challenge and dilemma in epidemiologic studies. Am Rev Respir Dis 1983;128:195209.

48. Baker JE, Reutens DC, Graham DF, Sterrett, GF, Musk AW, Hobbs MST, et al. Morphology of bronchogenic carcinoma in workers formerly exposed to crocidolite at Wittenoom Gorge in Western Australia. Int J Cancer 1986; 37:547-50".

49. Johansson L, Albin M, Jakobsson K, Mikoczy Z. Histological type of lung carcinoma in asbestos cement workers and matched controls. $\mathrm{Br} \mathrm{J}$ Ind Med 1992;49:626-30.

50. Minowa M, Hatano S, Ashizawa M, Oguro H, Naruhashi $\mathrm{H}$, Suzuki M, et al. A case-control study of lung cancer with special reference to asbestos exposure. Environ Health Perspect 1991;94:93-42.

51. Raffn E, Lynge E, Korsgaard B. Incidence of histological type among asbestos cement workers in Denmark. Br J Ind Med 1993;50:85-9.

52. Husgafvel-Pursiainen K, Hackman P, Ridanpää M, Anttila S, Karjalainen A, Partanen T, et al. K-ras mutations in human adenocarcinoma of the lung: association with smoking and occupational exposure to asbestos. Int J Cancer 1993;53:250-6.

53. Whitwell F, Newhouse ML, Bennett DR. A study of the histological types of lung cancer in workers suffering from asbestosis in the United Kingdom. Br J Ind Med 1974;31:298-303.

54. Vena JE, Byers TE, Cookfair D, Swanson M. Occupation and lung cancer risk: an analysis by histological subtypes. Cancer 1985;56:910-7.

55. Mollo F, Bellis D, Delsedime L, Bernardi P, Ardissome F, Piolatto G, et al. Autopsy indicators of exposure to asbestos and lung cancer. In: Riboli E, Delendi $M$, editors. Autopsy in epidemiology and medical research, Lyon: International Agency for Research on Cancer (IARC), 1991;141-7. IARC scientific publications, no 112.
56. Kimizuka G, Azuma M, Ishibashi M, Shimozaki K, Hayashi Y. Co-carcinogenic effect of chrysotile and amosite asbestos with benzo(a)pyrene in the lung of hamsters. Acta Pathol Jpn 1993;43:149-53.

57. Jackson JH, Schraufstatter IU, Hyslop PA, Vosbeck K, Sauerheber R, Weitzman SA, et al. Role of oxidants in DNA damage: hydroxyl radical mediates the synergistic DNA damaging effect of asbestos and cigarette smoke. J Clin Invest 1987;80:1090-5.

58. Weitzman SA, Stossel TP. Mutation caused by human phagocytes. Science 1981;212:546-7.

59. Ohshima H, Bartsch $\mathrm{H}$. Chronic infections and inflammatory processes as cancer risk factors: possible role of nitric oxide in carcinogenesis. Mutat Res. In press.

60. Prewitt TW, Chaudhri G, Pass H. Asbestos and interfon gamma synergistically induce murine macrophages to produce nitric oxide [abstract no 656]. Proc Am Assoc Cancer Res 1993;34:445.

61. Kodell RL, Krewski D, Zielinski JM. Additive and multiplicative relative risk in the two-stage clonal expansion model of carcinogenesis. Risk Anal 1991;11: $483-90$

62. Nigro J, Baker SJ, Presinger AC, Jessup JM, Hostetter $\mathrm{R}$, Cleary $\mathrm{K}$, et al. Mutations in the p53 gene occur in diverse human tumor types. Nature 1989;342: $705-8$.

63. Bos JL. ras Oncogenes in human cancer: a review. Cancer Res 1989;49:4682-9.

64. Kasai H, Nishimura S. DNA damage induced by asbestos in the presence of hydrogen peroxide. Gann $1984 ; 75: 841-4$.

65. Rydberg D, Kure E, Lystad S, Skaug V, Strangeland L, Mercy I, et al. p53-Mutations in lung tumours: reIationship to putative susceptibility markers for cancer. Cancer Res 1994;54:1551-5.

66. Wink DA, Kasprzak CM, Maragos CM, Elespuru RK, Misra M, Dunams TM, et al. DNA deaminating ability and genotoxicity of nitric oxide and its progenitors. Science 1991;254:1001-3.

67. Nguyen T, Brunson D, Crespi CL, Penman BW, Wishnole JS, Tannenbaum SR. DNA damage and mutation in human cells exposed to nitric oxide in vitro. Proc Natl Acad Sci USA 1992;89:3030 - 4.

68. Vainio H, Husgafvel-Pursiainen $\mathrm{K}$, Anttila S, Karjalainen A, Hackman P, Partanen T. Interaction between smoking and asbestos in human lung adenocarcinoma: role of K-ras mutations. Environ Health Perspect 1993;101 suppl 3:189-92.

Received for publication: 24 February 1994 